\title{
The Tower of Torrenostra in Torreblanca, Spain: Studies and Documentation for a Landscape Archaeology Reconstruction
}

\author{
FABRIZIA GIANNOTTI, ANDREA LEONARDI, ANDREA PASQUALI \\ University of Florence, Italy
}

\begin{abstract}
During the survey campaign of the TOVIVA research project, "Torres de vigía y defensa del litoral valenciano. Generación de metadatos y modelos 3D para su interpretación y efectiva puesta en valor," many of these towers were digitally surveyed using a 3D laser scanner and terrestrial and aerial photogrammetry. The survey campaign took place in April 2015 and after gathering the data, a phase of elaboration successfully produced the architectural drawings of plans, elevations and sections. A part of this documentation was presented on the poster "When an isolated building becomes a guideline for the urban pattern. The case of 'Torrenostra' in Torreblanca, Castellón, Spain," by T. G. Piqueras, S. Giraudeau and $A$. Leonardi in 2015. In this paper, we want to present the next stage of the work, aimed at reconstructing the original landscape around it. Although today the tower is surrounded by other buildings, the situation was different in the past, when the tower was isolated on the coast. Rediscovering the original landscape of the city could be a topic of interest and discussion in the Museum of the Territory of Torreblanca. This presentation could take place inside the tower and explain to visitors the history of the territory and its evolution, involving the structure of the tower itself, its changing shape and its value. The $3 \mathrm{D}$ reconstruction, both digital and tangible, is also a good way to involve children and adults alike, adding a special value to the historical building.
\end{abstract}

Key words:

3D laser scanner, terrestrial and aerial photogrammetry, original landscape, museum, 3D reconstruction.

SDH Reference:

Fabrizia Giannotti, Andrea Leonardi, Andrea Pasquali. The Tower of Torrenostra in Torreblanca, Spain: Studies and Documentation for a Landscape Archaeology Reconstruction. SDH, 1, 2, 735749.

D0I: $10.14434 /$ sdh.v1i2.23244

\section{INTRODUCTION}

The tower of Torrenostra is one example of military architecture of the sixteenth and seventeenth centuries, developed on the east coast of Spain in the presence of a particular socio-political context and technological progress. In 1557, when Philip II ascended the throne, he began to support the

Author's address: Fabrizia Giannotti, Andrea Leonardi, Andrea Pasquali, Dept. of Architecture, University of Florence, Florence, Italy; email: f.rizia@hotmail.it, leonardi.andrea93@gmail.com, pasqualiandrea@yahoo.it

Permission to make digital or hardcopies of part or all of this work is granted without fee according to the open access policy of SDH.

(C) 2017 SDH Open Access Journal 
ambitious project undertaken by Bernardino de Cardenas, Duke of Maqueda, for his father. The project involved the creation of a network of watchtowers to defend the coast, to spot pirates in advance and to create a first line of defense against them (Fig. 1). An important figure of this period was Giovanni Battista Antonelli, a military engineer who designed many towers, whose work was continued by other members of his family throughout the sixteenth and seventeenth centuries. Nowadays, these military structures form an important architectural heritage that has lost its main characteristic: unity. The Toviva project aims to conduct studies useful to the improvement of these towers that were once part of a single defense system, but which, today, are mainly abandoned.

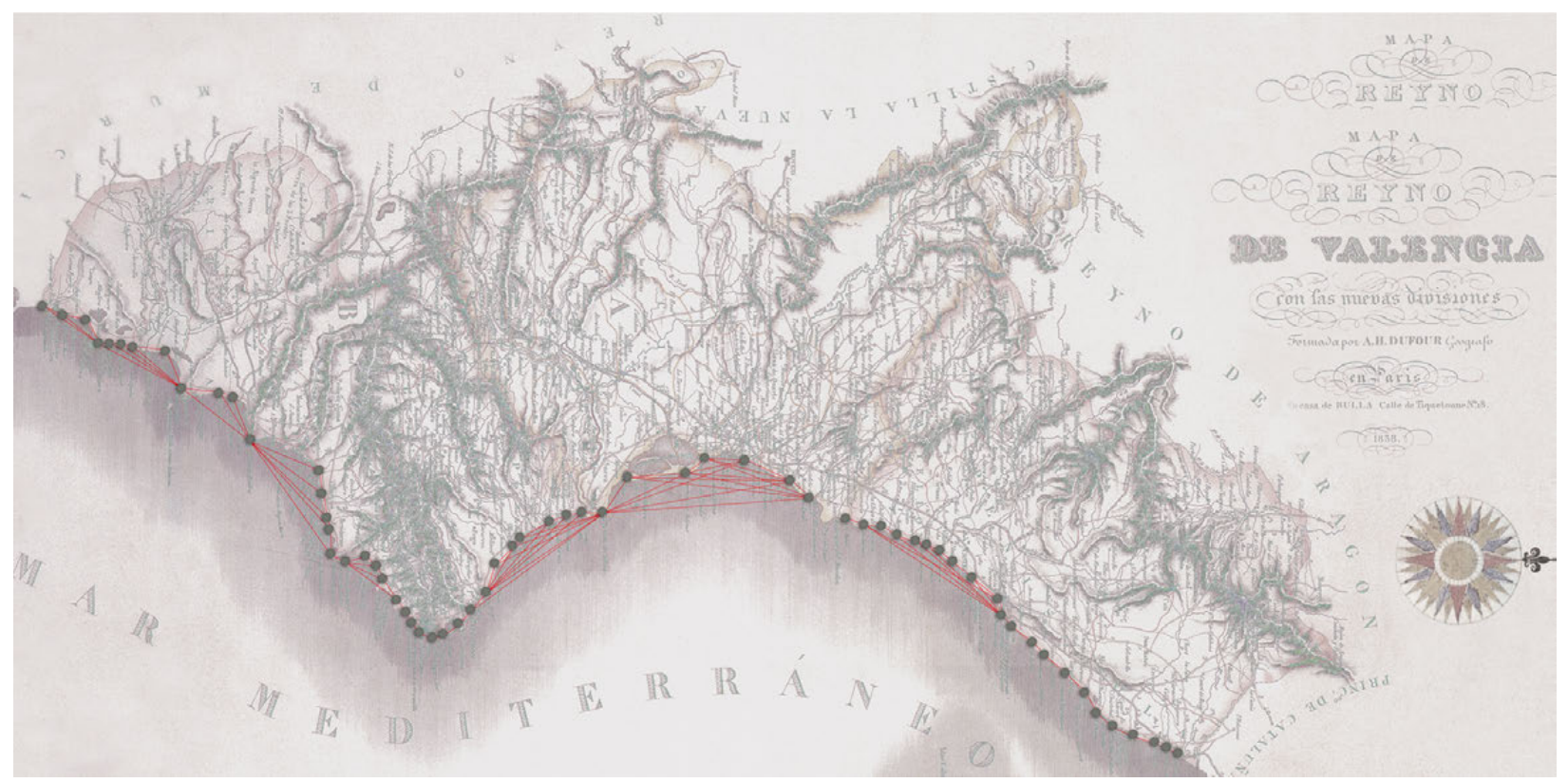

Figure 1. The system of towers of the Valencian coast.

\section{CHARACTERISTICS OF DEFENSIVE SYSTEM}

The system of towers on the Valencian coast, in use since ancient times and widely used by the Muslims, was passive and preventive. Built mainly for sighting and for the organization of the defense, it was made up of elements resistant to cannonade by pirates.

Their primary function was to ensure a flow of constant information on sightings to neighboring towns and towers, allowing for the possibility of setting getaways or entrenchment. The location of the towers was fundamental to the control of the surrounding territory, guaranteeing the surveillance of headlands, coves, ravines and fresh water springs. These sighting sites were strategically built on hills, from which it was possible to enjoy a broad view of the surrounding territory. The points to be monitored were not only those where the pirates might land, such as bays or protected places near the villages, but also the river mouths, where they could penetrate the territory, and areas where they could stop and take on supplies, for example near sources of fresh 
water. Therefore, it was crucial to ensure visibility between adjacent towers, which were generally built at a distance of a league, a measure that halved in the case of mountainous terrain and could double if it were flat.

\subsection{Almenaras}

The towers communicated through warning systems (almenaras) that included the passage of information through the guards, who moved from one tower to another, spreading the news. This was in addition to signals in the visually connected towers in the case of the presence of enemy vessels. When a suspected ship got too close to the coast, soldier on horseback (atajador) who sighted it fired a warning shot in the air to ask the boat to get closer to be identified.

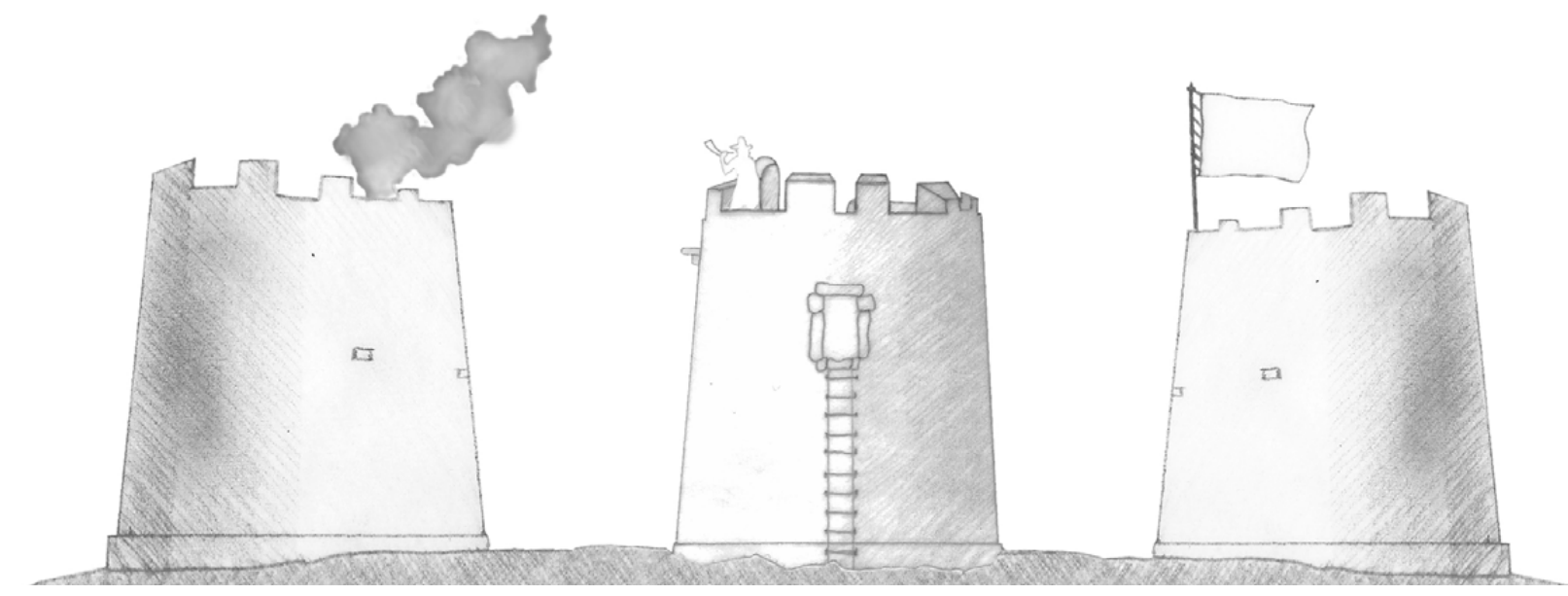

Figure 2. Warning system: signal fires, acoustic signals with a horn and the seguro signal.

In the event that the ship tried to escape, a warning of a possible attack was given. As soon as the ship was identified as a pirate, the defenders lit signal fires with smoke blown in the direction of the origin of danger. At the same time, the atajadores moved to the contiguous towers and into the towns to sound the alarm. In addition to visual warnings, it was also possible to use acoustic signals, especially in case of low visibility. Horns and bells were used, and a pre-established code allowed the passage of detailed information about the enemy. In the case that no danger was present, a flag was raised on the towers to allow the local population to return to everyday activities, such as hunting and fishing: this was the seguro (safe) signal (Fig. 2).

\section{SITE}

The Tower of Torrenostra, built between the XVI and XVII centuries, is located in the city of Torreblanca, Spain. It is one of the towers on the Valencian Coast, built by Ing. G. B. Antonelli, that still stands. Torreblanca is a municipality located on the coast of the province of Castellón and bathed by the Mediterranean Sea. Just three kilometers from the village is the sandy Torrenostra beach where the tower is situated. Thanks to the construction of this coastal defense tower on the beach at the end of the XVI century and beginning of the XVII, the fishing village of Torrenostra was able to 
grow. Over the centuries, the tower and its surroundings have undergone profound changes, as a result of human settlement. In fact, throughout the XIX century, when the Ottoman threat ceased, aixoplucs, occasional shelters for families who were dedicated to fishing activity in these waters, were built on the formerly uninhabited seafront (Fig. 3).
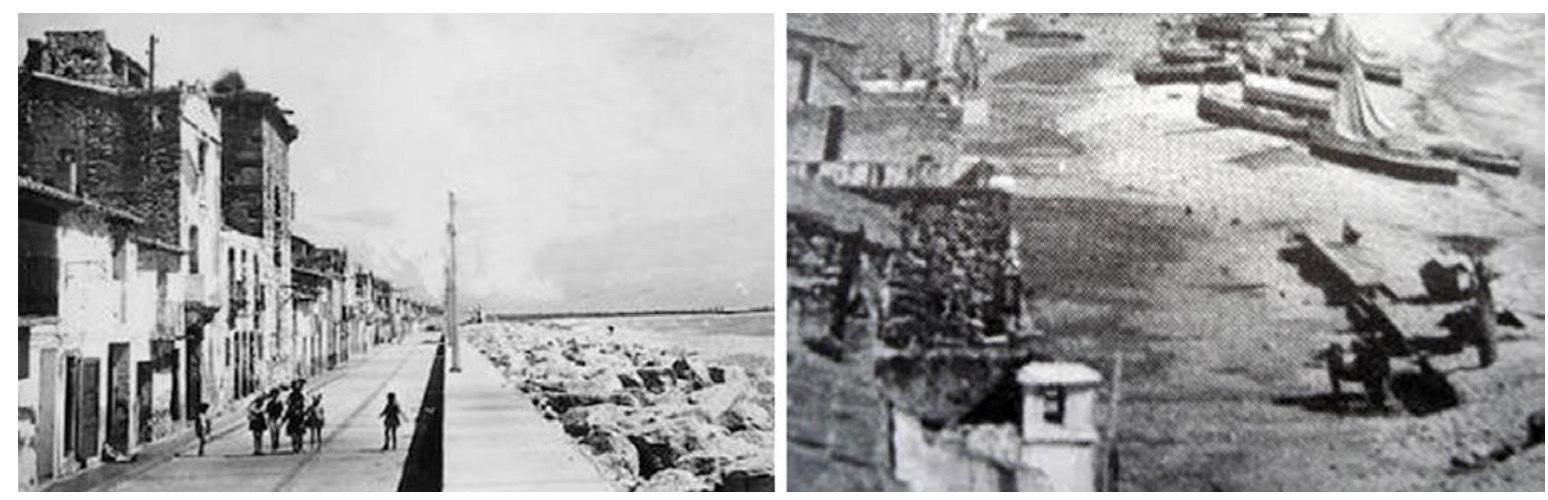

Figure 3. Historical image of the waterfront and ancient fishing village.

At the beginning of the XX century, the typical "houses of a ground floor and one or two spans" were built next to each other and aligned with the eastern front of the tower, which overlooks the sea. Later, the tower became private property and its original appearance underwent several changes. In subsequent years, the denial of permission to build the pier dashed the hopes of a growing population and led to the migration to more prosperous neighboring areas, such as Peñíscola, with major piers.

Since the 1960s, when the development of tourism caused an interest in this place, the emergence of apartment blocks and new housing replaced the old fishermen's houses and the old retaining wall was transformed, thanks to the construction of breakwaters, into a wide sandy beach. The urban development that took place in Torrenostra was spontaneous because of the lack of urban planning and land use regulations (Fig. 4). This led to the annexation of more housing units on the structure of the tower, which is now integrated into the block of buildings located along the coast.
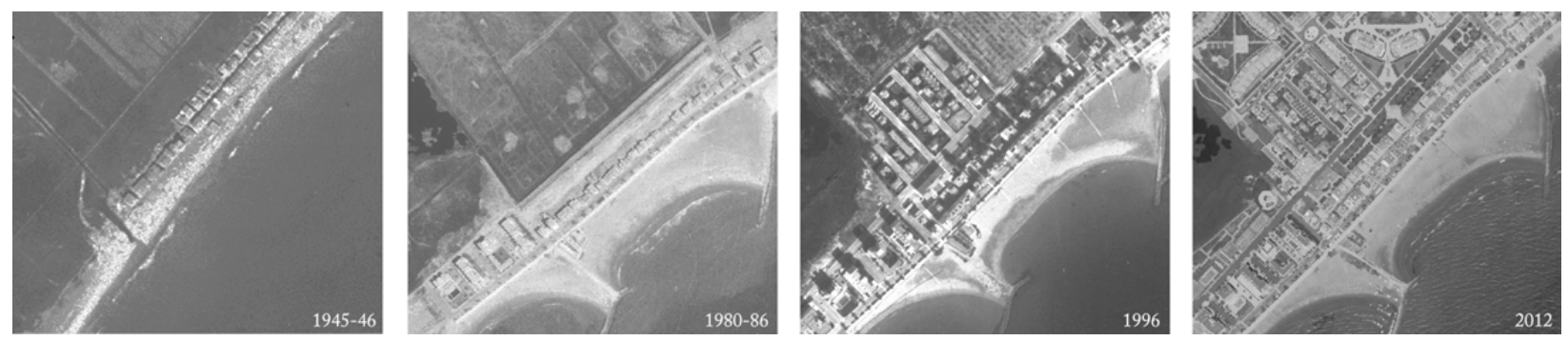

Figure 4. Aerial views of the urban development of Torrenostra.

In 1984, spatial planning of Torreblanca to regulate the growth and urban development of Torrenostra was finally approved, and in February 2002, the tower was declared to be of cultural interest in the 
area of the Architectural and Environmental Heritage of Education, Culture, Research and local government Sport Generalitat Valenciana.

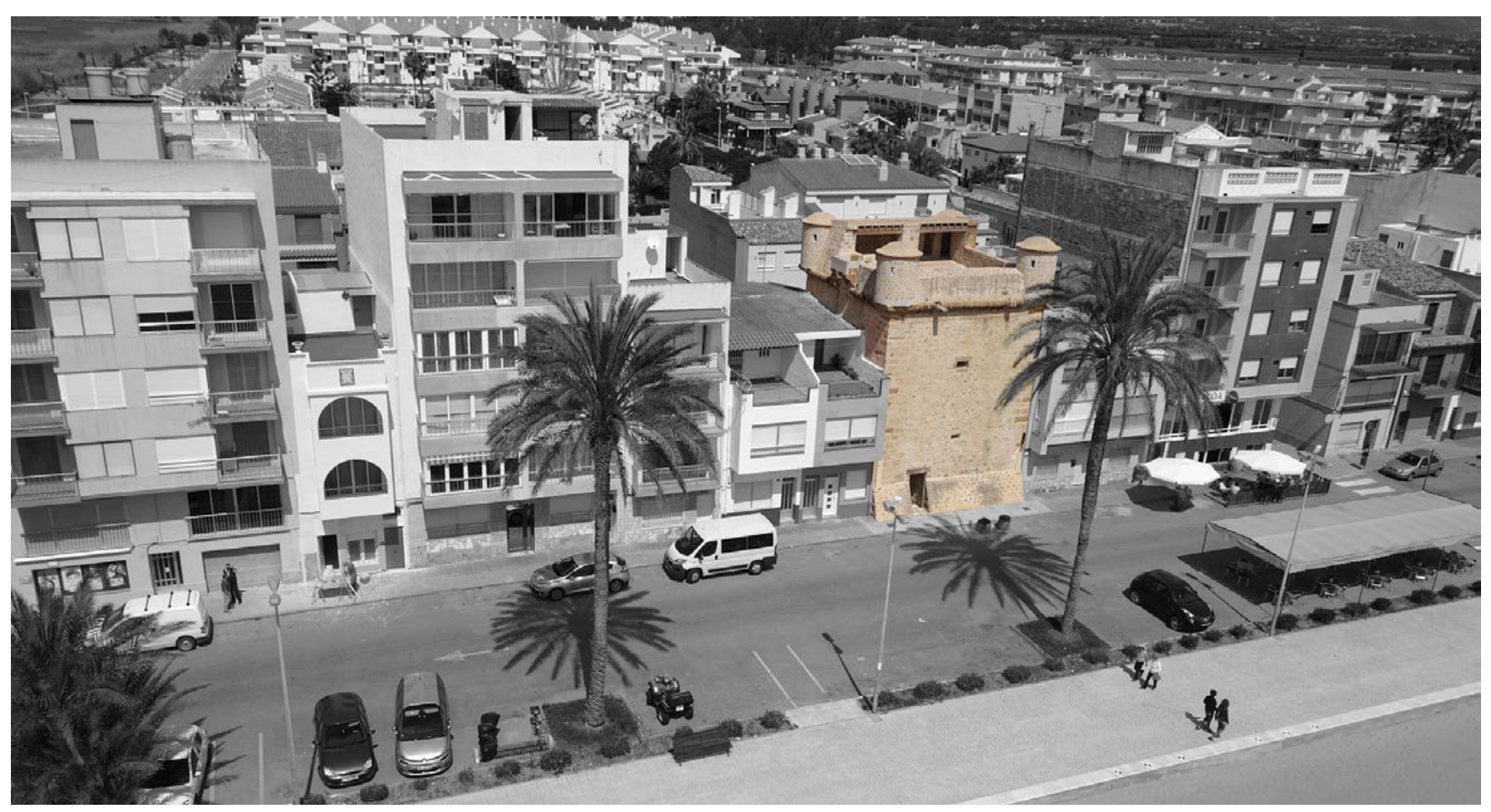

Figure 5. The tower today surrounded by other buildings.

Between 2005 and 2006 it was restored and, since its restoration, can be visited both during the summer and winter seasons.

\section{FORMAL DESCRIPTION AND RESTORATION}

The Torrenostra tower is a typical example of a coastal square tower. However, it is now incorporated into new building and it is part of the strip of buildings that are on the city's waterfront (Fig. 5).

It is thought that the tower was built in the late seventeenth century (the first documented reference known coincides with the Ordinances of 1673), as an intermediate tower between Cap I Corb and Torre de la Sal, to protect the coastal area and the pier of Torreblanca. It was one of the watchtowers in the defense system of the coast of Castellón (Fig. 6).

Its orientation is toward the sea, which is located in the southeast. Its square floor plan measures externally about $9 \mathrm{~m}$ and internally $4.45 \mathrm{~m}$, while the walls are about $2.30 \mathrm{~m}$ thick. These dimensions may be put in relation with the measurement unit of that time: the wall thickness is 10 palms, while the inside is 20 , thus obtaining a total of 40 external palms. The overall height, between the ends of the inclined base and the frame, is $9 \mathrm{~m}$ : so, this facade is a 40 palms square. Even if the actual access 
level is well above the original, the presence of a clearly visible base with a very marked inclination means that we cannot be sure that it matches the original.

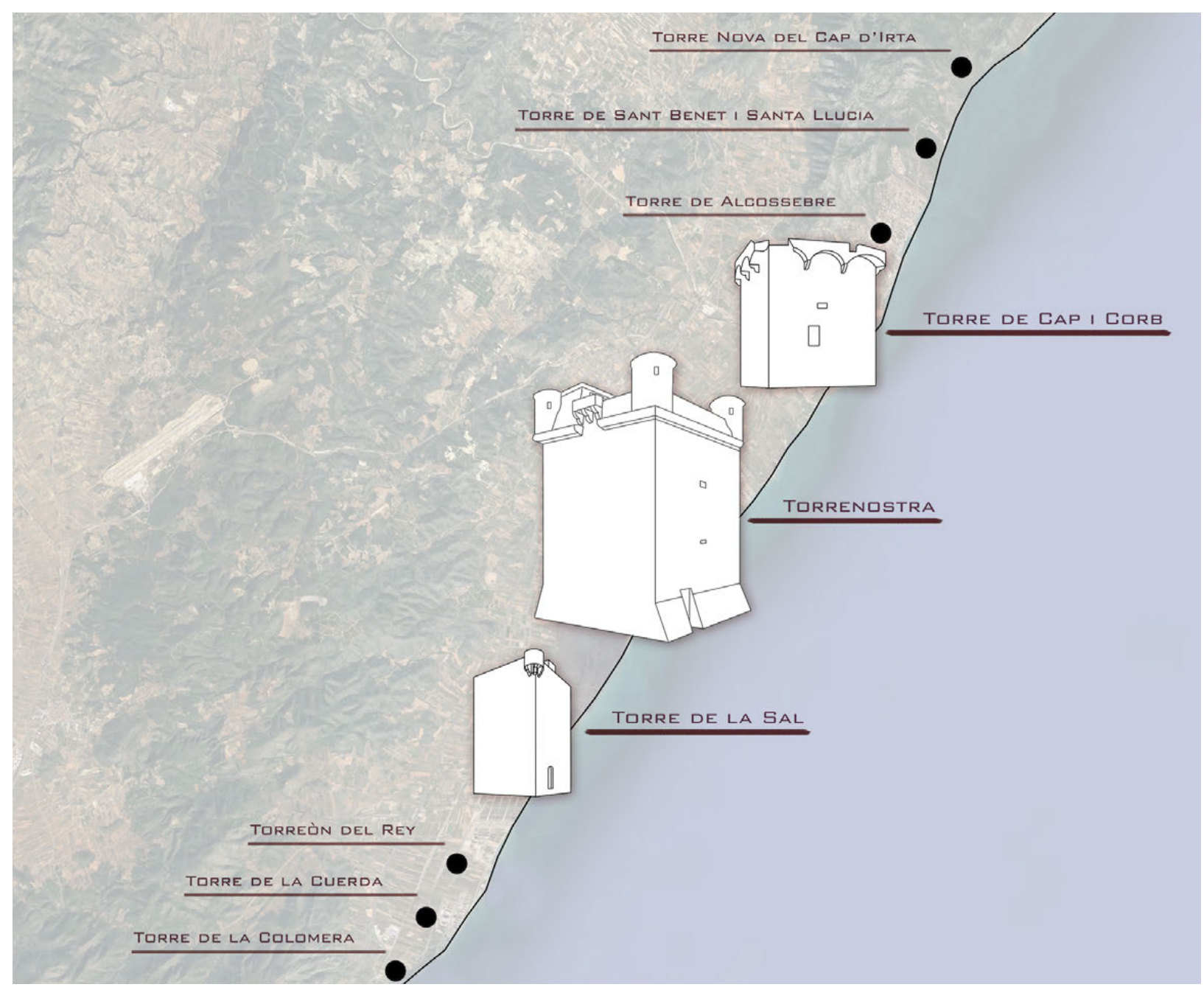

Figure 6. Watchtowers of the coast of Castellón.

All levels of the tower are connected by a spiral staircase with a central pillar, with a total of 6 internal diameter palms, located in a corner inside the wall thickness. The steps consist of carved stone blocks, an original and exceptional element (Fig. 7). 

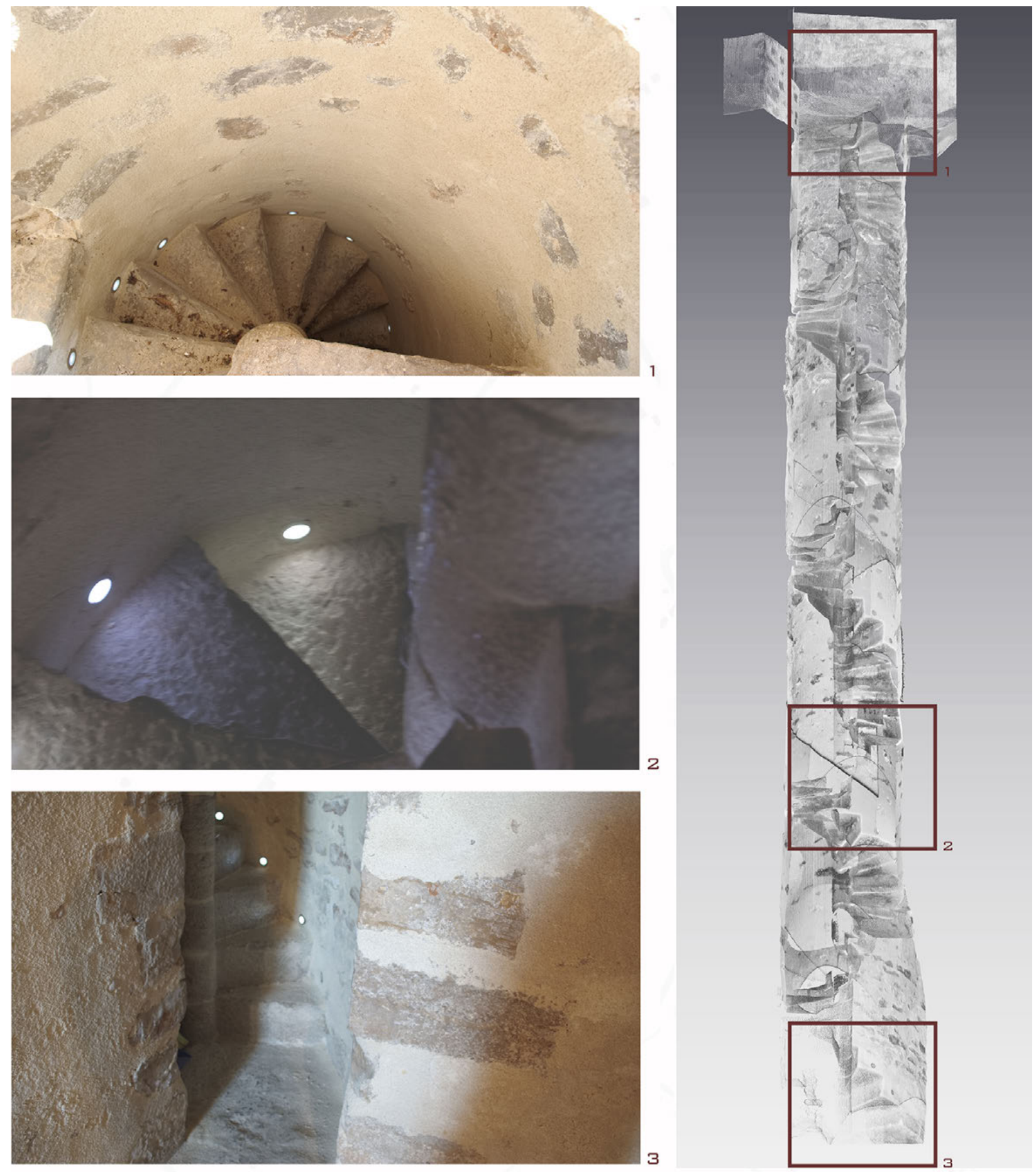

Figure 7. Spiral staircase with a central pillar. 
In all levels there are small apertures, loopholes, made of stone and brick, and at the second floor, above the original entrance door, there is a window with an architrave, now walled-up. The rooms of the three levels are covered by three barrel vaults. Those of the first and second levels develop in a parallel direction with respect to that of the coast, while that of the third level has a development perpendicular to the previous. The tower ends at the top with a stone molding, and a terrace surmounted by four cylindrical angular towers. A rectangular matacan, a projecting parapet with a hole in the floor, is placed above the original access door (Fig. 8).
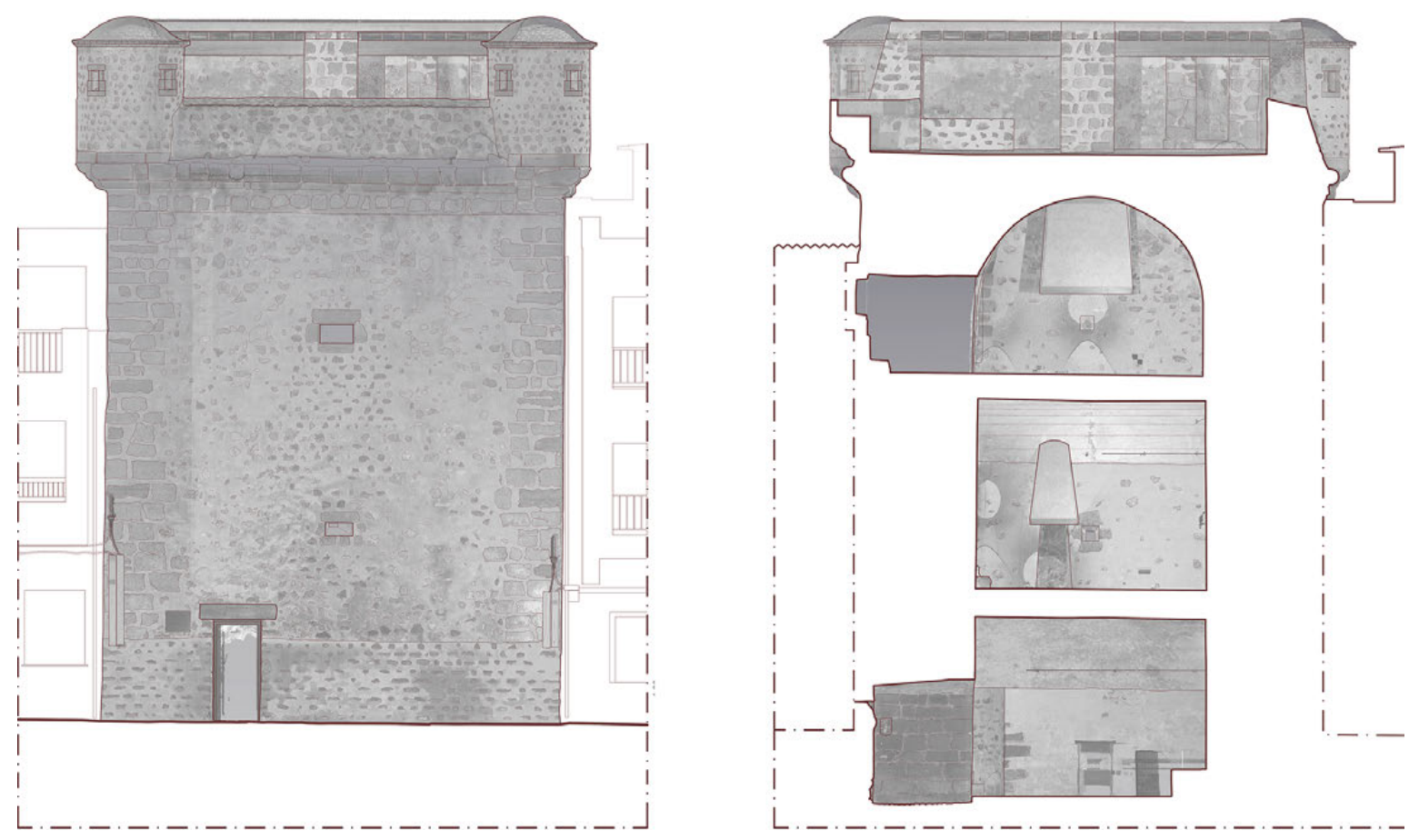

Figure 8. East elevation and section of the tower.

It is one of the best-preserved examples of a costal tower. In 2006, a restoration was completed that allowed us to recover its original state, which had been greatly altered over the years. Fortunately, even before the restoration began, the tower did not present serious problems in its construction or structural integrity, although the existence of certain pathologies required several restoration interventions (Fig. 9).

In fact, having completed the cleaning and removal all the improper elements that had no historic/architectural value, we immediately started to consolidate the structure and above all to rebuild all the missing elements of which visible traces were left or whose existence was known from documentary sources.

The most important interventions were the reconstruction of the scarp in the basement (with probably an inclination not similar to the original one), the restoration of the facade openings, the reconstruction of the parapet, the four corner towers (with respective loopholes) and the matacan 
above the original entrance (Fig. 10). The restoration performed is very different from the "minimum intervention" typical of critical restoration, which involves only the steps needed to remove improper additions and to consolidate the structure to ensure its conservation.
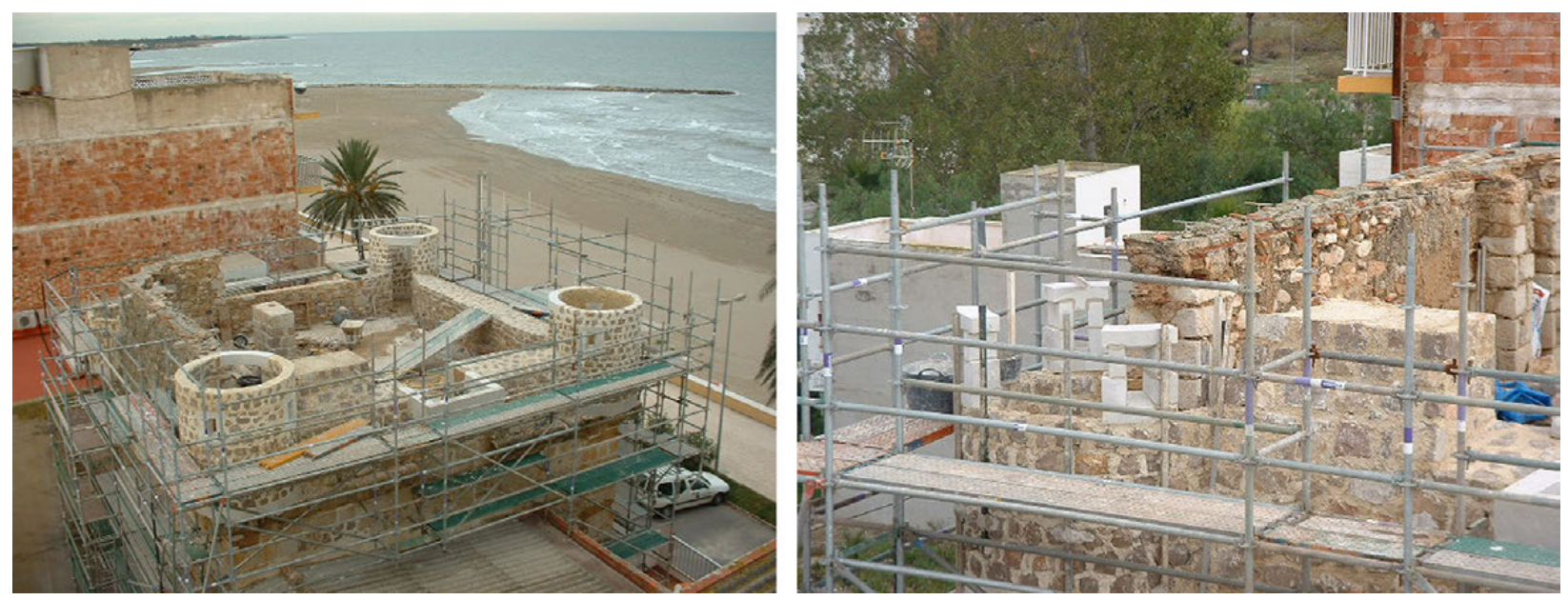

Figure 9. Pictures of the roof restoration.
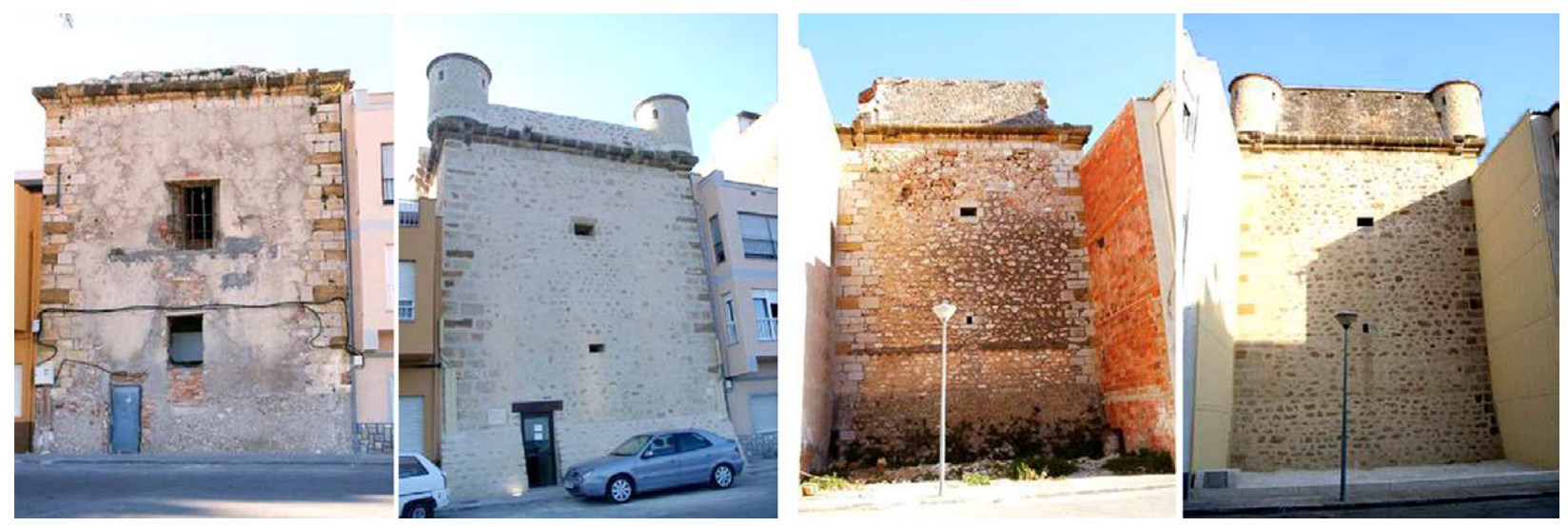

Figure 10. Comparison of the elevations before and after restauration.

Thanks to this intervention, the original and unified image of the tower has been restored, keeping its essence as a watchtower, not precluding uses for purposes other than the control and coastal defense (not necessary nowadays), but especially ensuring its stability and its preservation over time. 
1:744 F. Giannotti et al.

\section{SURVEY METHODS, EQUIPMENT AND SOFTWARE}

In April 2015, a group of professors and researchers of the Heritage Restoration Institute of the Polytechnic University of Valencia and the Department of Architecture of the University of Florence conducted a survey campaign of eleven days duration, aimed at architectural survey of several towers with similar characteristics, including Torrenostra.

An entire day was dedicated to surveying this tower. It was digitally surveyed using a 3D laser scanner (of the type Z + F - 3D laser scanner IMAGER 5006h), and then terrestrial and aerial photogrammetry was done (with a Quadcopter Dronequad). This was very useful for the survey of the exterior, because through it was possible to obtain otherwise unobtainable images from different viewpoints.

The objective of the survey was the digitization of internal and external surfaces of the tower and its graphic representation, which allowed us to locate and read the construction system, its elements and materials, so that we could see any structural or functional issues arising from changes that had occurred over the centuries. Through this work, it was possible to highlight the potential and the peculiarities of the tower and to understand its evolution. This was characterized by the presence of new elements found in the restoration of 2006, and other original and still visible structures, such as the original spiral staircase. In addition, structures such as the old entrance, that had been hidden by buildings juxtaposed to the tower, were "uncovered" by the restoration.

After the data gathering, a phase of elaboration produced architectural drawings of plans, elevations and sections. The data obtained from the 51 scans were imported into the Leica Geosystems Cyclone 9.1 software in order to combine the individual point clouds from various scans and to get to a single final cloud (Fig. 11).
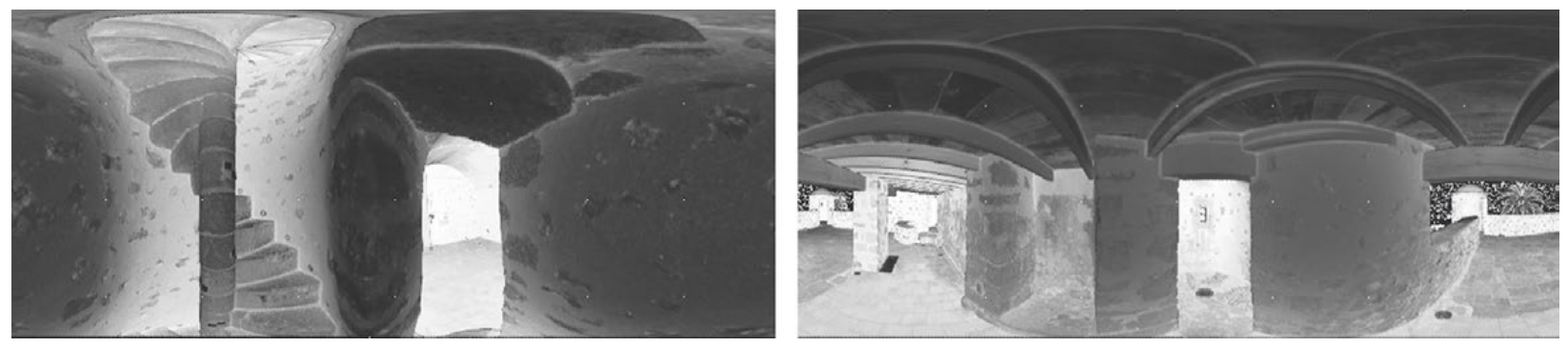

Figure 11. Individual point clouds from various scans.

The final three-dimensional point cloud was subsequently imported into the software Bentley Pointools Edit Pro 1.5, which allows selecting, editing and segmentation of the cloud. In this software, the cloud of points through the "Plane Shader" function can be displayed with a range of shading options and in different chromatic scales that allow an easier interpretation of the data and the production of more detailed images (Fig. 12). 

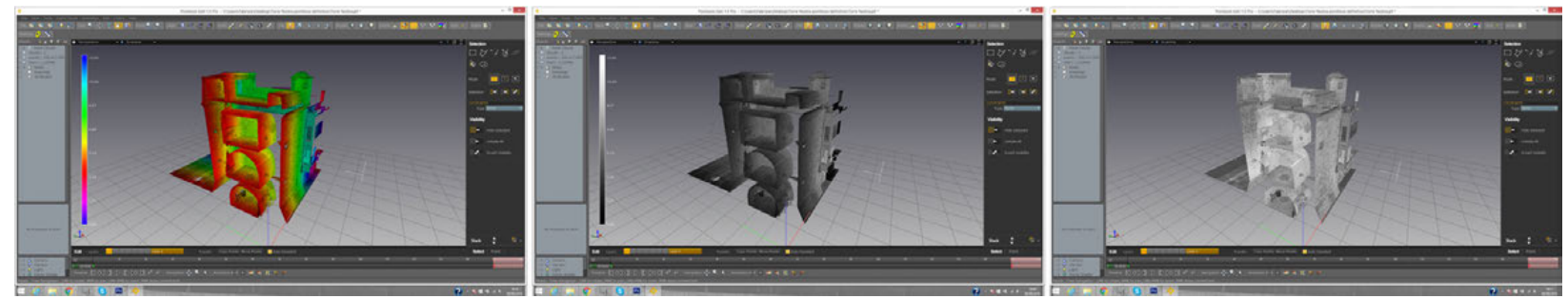

Figure 12. Plane shader function.

Through the ClipBox function, it was possible to incorporate the object in a box, whose limits allowed us to "cut" a specific part to obtain planes and sections in the desired points. Finally, it is possible to generate snapshots at high resolution (300 DPI), in scale and in the desired format (in this case a scale of 1:50 and .tiff format), which are useful for the actual digital reconstruction of the tower. These snapshots were then placed on Autodesk Autocad 2015 to create the two-dimensional drawing.

As the last step, all this was drawn on Adobe Photoshop CS6 to get to a better end-result graph that would allow a simpler reading of the tower

\section{3D RECONSTRUCTION}

The work involved the production of two 3D reconstructions to reproduce the current state and the hypothetical initial state of the tower (Fig. 13) is useful for understanding better the differences between them. In effect, if today the tower is presented surrounded by other buildings on the two lateral sides, the situation was very different in the past, when the tower was totally isolated on the coast. The current condition, therefore, must be understood as the result of several interventions over centuries, prompting a need for a proper interpretation of the definition of the original features. The hypothetical 3D reconstruction is based on the study of the main defensive elements of the tower, on the analysis of the types with which these elements appear in the other towers of the defensive system of the Valencian coast and, of course, on the historical documentary sources.
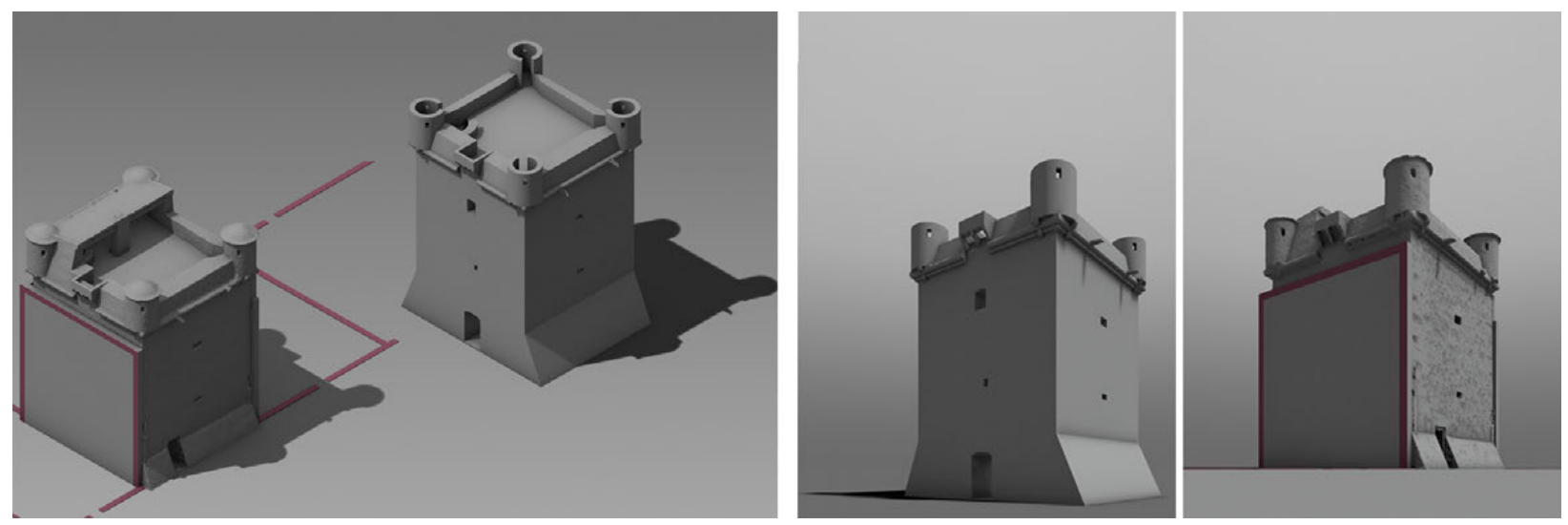

Figure 13. 3D reconstruction reproducing the current state and the hypothetical initial state of the tower. 


\section{1:746 F. Giannotti et al.}

In our hypothetical reconstruction:

- the angular towers, useful for spotting the enemy and for attacking him from above, have been imagined without the covering bricks added during the restoration because this feature does not appear in any other tower;

- the matacan, a projecting parapet with a hole in the floor placed above the door and useful for defence from above, has been maintained as it was built during the restoration, on the southwest side of the tower, where the original entrance was;

- the loopholes (long and narrow openings in the wall) have been restored in all elevations of the tower;

- the parapet has been retained as it was built during the restoration, with the upper part inclined to prevent the enemy from finding points to anchor;

- the original entrance, which today is walled, has been re-opened on the west side of the tower;

- as for the scarp wall, which today is on the southeast and northwest sides of the tower, we preferred not to make risky and unfounded assumptions because we had no certainty, neither regarding the actual presence nor about the type.

\section{THE MUSEUM}

In order to give completeness to the studies of the Toviva project, aimed at the survey and knowledge of the Spanish coastal towers, we wanted to provide our tower with a project proposal that would complete the path of knowledge undertaken. In addition, we want to provide useful operational ideas in order to solve the problems and support the observations found during the survey and the subsequent processing of the data.

The rediscovery of the original landscape of the city could be an interesting topic to explain in a Museum of the Territory of Torreblanca. This could take place inside the tower and could explain to the visitor what the the territory was like in the past and how it has evolved over time, in particular the changing shape and value of structure of the tower itself,.

The proposal of the museum was born from the desire to tell and enhance the history and the essence of Torrenostra tower. Our aim is to emphasize and bring out the identity of the tower, now blurred by the context in which it is inserted, creating an incentive to keep active this wonderful example of fortified architecture, too little appreciated and known only superficially. The intention is to create inside the tower itself a dynamic space that can tell the story not only of the tower and the territory in which it is located, but will also present the historical context that, in fact, has determined its existence. The tower and its history will be connected to the other towers, in order to recreate, at least in memory, the old unitary system of towers.

In the tower, we want to create a combination between the rigidity and the "story" of the stone, compared with the "modernity" of steel and glass, in order to create an attractive environment without changing the essence of the towerthat will be enjoyed by tourists and local visitors. The tower, which until now has not yet found its rightful "place" inside Torrenostra, will perform several 
functions from the exhibition hall to the projection room, in order to create a stimulating and attractive space capable of rekindling interest in this architecture that perhaps many residents now take for granted, without knowing its history and understanding its true value (Fig. 14).

The museum concept, born with the goal of coexistence, has the following objectives:

1. To tell and show, through exhibition panels and videos made with the help of the drone, the history of the site where the Tower stands, the ancient desert coast, from the first settlements of fishermen until today;

2. To tell the story of the Kingdom of Spain and the birth of the defensive system of towers, describing its characteristics and dynamics; ;

3. To show and explain, through exhibition panels and through a three-dimensional model, the structure of the tower, from the materials to the typical characteristic elements of the fortifications, highlighting the evolution undergone by the same during the course of the centuries;

4. To create aggregation environments, reinterpreting the original function of the tower in relation to our times, setting it as an element of identity not only of the landscape but also of its inhabitants and their culture.
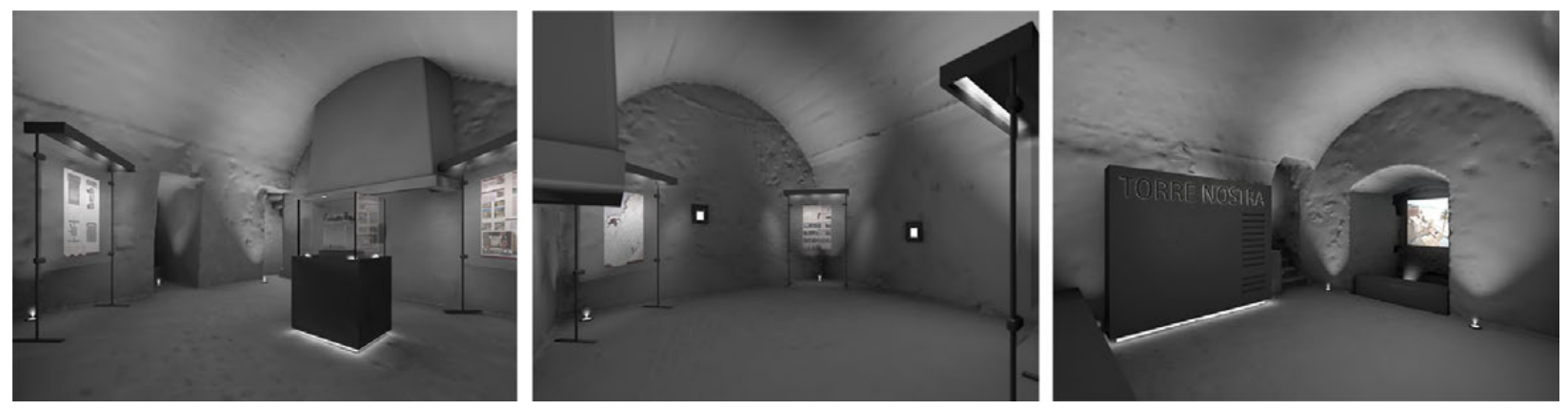

Figure 14. Internal views of the Torrenostra museum.

These objectives of our design proposal will be accomplished by the layout of the tower environments; the designer's intervention will make the spaces useful, creating a setup able to correlate the problems identified with the space for the achievement of the historical and cultural essence inherent in the architecture of the tower.

We will try to realize everything without compromising the rigid architecture of the tower, trying instead to interact with it with the maximum respect, promoting its spatial and functional versatility, creating within it a path to guide the visitor through the characteristic elements of the tower, and the different spaces that facilitate the aggregation and collective aspects. In this way, the 3D reconstruction visible in the tower, both digital and tangible, is also a good way to involve children and adults at the same time, adding a special value to an historical building. The choice of materials and colors of the supports and of the theca was made, on the one hand, favoring a "rough" material, 


\section{1:748 F. Giannotti et al.}

iron, as the stone of the tower, and on the other hand, we have chosen to use the glass to leave visible transparency in the wall system. The panel sections and profiles, slightly oversized, were chosen to respond to the massive character of a fortified place. Because of the low level of natural light and the point lighting system, created during the restoration by placing four corner spots at each level of the tower, we chose to provide for each panel LED lights incorporated into the upper section of the structure, so as to illuminate each work exhibited in a complete and uniform way.

Regarding the theca, placed at the center of the last level of the tower and consisting of a square base with an aluminum frame and an upper glass cube, the illumination was placed below, to emphasize its presence at the center of the room as if it were suspended in space and time. The abovementioned lighting systems, not anchored to any part of the structure, implement the aspect of reversibility of the panels (adjustable and removable) and the entire design intervention.

\section{CONCLUSION}

The 3D reconstruction, both digital and tangible, adds a special value to a historical building, reestablishing the tower in a circuit of fruition, military in the past and cultural now. Virtual and material models will allow users to understand the state of the landscape of the past, imagining the situation and relationship of our tower with its place.

The museum proposal is aimed at increasing the use and the functional reinterpretation of the tower, which is thus related to our contemporaneity. Along with it, the survey of the tower provides a data archive for future reflection and comparison between its previous state and the subsequent restoration; this is useful for assessment and eventually for the evolution of restoration methods, restructuring and rebuilding of the Iberian school.

All this helps to provide a comprehensive view of the historical evolution of the tower, archiving with scientific methods all the steps of the structural evolution of the tower, but also of its restoration work.

The goal is to configure the tower not only as a symbol and a testimony of the past that characterizes the coastal landscape, but also as an element of identity of the local culture and inhabitants who interact with it, continuing to bring it to life in our time.

The desire is therefore to create a new hub in a community trying to create an evolutionary input targeted mainly to an increase in cultural tourism, and the consequent increase of the territorial possibilities aimed at seeking new users and visitors.

\section{REFERENCES}

R. Atzeni and V. Naldini. 2014. Guardando il tempo da una torre sul mare. Università degli Studi di Firenze, Tesi di laurea in Architettura, Firenze.

S. Bertocci and M. Bini. 2012. Manuale di rilievo architettonico e urbano. Novara: Città Studi edizioni. M. J. V. Boira. 2007. Las Torres del Litoral Valenciano. Valencia: Generalitat Valenciana.

V. C. Cerdàn. 2012. Torres de vigía y defensa del litoral valenciano (III): de la torre de Burriana a la Torre de El Puig, Proyecto Final de Grado. Taller 12, Conservaciòn del Patrimonio. Estudios 
previos Escuela Técnica Superior de Ingenierìa de Edificaciòn. UPV, Valencia.

A. Frascari etal, 2015. Digital construction for analysis: the Scalambri defensive system in Sicily. In P. R. Navarro (ed.), Defensive architecture of the Mediterranean. XV to XVIII centuries, vol. I, 307314. Valencia.

T. Gil Piqueras et al. 2015. When an isolated building becomes a guideline for the urban pattern. The case of "Torrenostra" in Torreblanca, Castellòn, Spain. In Proceeding of the $20^{\text {th }}$ Conference on Heritage and New Technologies. Vienna: Ed. Museen der Stadt Wien - Stadtarchäologie. PAGES?

A. J. Latorre 2012. Torres de vigía y defensa del litoral valenciano (II) : de la Torre de la Sal a la Torre de Mijares, Proyecto Final de Grado. Taller 12, Conservaciòn del Patrimonio. Estudios previos Escuela Técnica Superior de Ingenierìa de Edificaciòn. UPV, Valencia.

R. O. Lerma Traver. 2012. Torres de vigia y defensa del litoral valenciano (IX). De la torre de Agua Amarga a la torre de la Horadada, Proyecto Final de Grado. Taller 12, Conservaciòn del Patrimonio. Estudios previos Escuela Técnica Superior de Ingenierìa de Edificaciòn. UPV, Valencia.

B. Prades and Juan Emilio. 2013. Gentes, Costumbres, Tradiciones, Historias, y Paisajes de Tierras Castellonenses: Trazos de la Historia Marinera de Torrenostra-Torreblanca. http://torrenostra.blogspot.com.es/2013/02/torrenostra-historia.html

A. F. Requena. 1997. La denfensas de las costas valencianas en la época de los Austrias. Alicante.

P. Rodriguez Navarro. 2015. Defensive architecture of the Mediterranean. XV to XVIII centuries Vols. I and II, Valencia.

P. Rodríguez Navarro et al. 2015. Metodología integral para la documentación de las torres de defensa de la costa valenciana.In Defensive Architecture of the Mediterranean XV to XVIII Centuries, Vol. 1. Valencia: Editorial Universitat Politècnica de València, 312-328.

M. J. Sànchez Mora. 2013. Torres de vigìa y defensa del litoral valenciano (VI). De la Torre del Gerro a la Torre del Descubridor, Proyecto Final de Grado. Taller 12, Conservaciòn del Patrimonio. Estudios previos Escuela Técnica Superior de Ingenierìa de Edificaciòn. UPV, Valencia.

A. E. Soler. 2015. Las torres de defensa del litoral: Sant Vicent (Benicàssim) y Torrenostra (Torreblanca). Castellón, Spain. Estudio arquitectónico y constructivo. In P. Rodríguez-Navarro, ed. Defensive Architecture of the Mediterranean. XV to XVIII centuries, Vol I. Editorial Universitat Politècnica de València, 167-174. DOI: http://dx.doi.org/10.4995/FORTMED2015.2015.1690

B. R. Vila. 2013. Torres de vigía y defensa del litoral valenciano (I): de la Torre de Sol de Riu a la Torrenostra. Proyecto Fin de grado. Tutor: Pablo Rodriguez. Inédito. Universidad Politécnica de Valencia.

Received March 2017; revised July 2017; accepted August 2017. 